\title{
CO Desorption and Absorption in Molten Steel: A Review
}

\author{
Zhuangzhuang LIU, ${ }^{*}$ Peter Tom JONES, Bart BLANPAIN and Muxing GUO \\ Department of Materials Engineering, KU Leuven, Kasteelpark Arenberg 44, Leuven, BE-3001 Belgium.
}

(Received on August 27, 2020; accepted on December 9, 2020; J-STAGE Advance published date: January 23, 2021)

\begin{abstract}
Previous work on the mechanism of carbon monoxide absorption and desorption from liquid steel/iron is reviewed. The experimental set-up employed in these studies is summarized and the characteristics of each methodology are discussed and compared. The reaction kinetics, particularly the rate-limiting step of the CO gas-molten steel/iron reaction is analysed with respect to experimental parameters, comprising temperature, $\mathrm{CO}$ partial pressure in the gas mixture, gas flow rate, crucible materials, and carbon and oxygen content in the steel/iron. To further understand the $\mathrm{CO}$ absorption and desorption mechanisms in liquid steel, suggestions for future work are provided.
\end{abstract}

KEY WORDS: steelmaking; CO absorption and desorption; gas-liquid reaction kinetics.

\section{Introduction}

The dissolved carbon and oxygen in molten steel to form carbon monoxide along with carbon monoxide absorption by liquid steel (i.e. carbon monoxide dissolving into liquid steel) are the most important gas-metal reactions in metallurgical processes, especially in iron and steelmaking operations. ${ }^{1-3)}$ For instance, the decarburization of steel in Basic Oxygen Furnace (BOF) ${ }^{4,5)}$ and Electric Arc Furnace (EAF) steelmaking ${ }^{6}$ processes can be understood through the reaction

$$
\underline{\mathrm{C}}+\underline{\mathrm{O}} \rightleftharpoons \mathrm{CO}(\mathrm{g})
$$

with equilibrium constant $\mathrm{K}$

$$
\log \mathrm{K}=\log \left(\mathrm{P}_{\mathrm{co}} /\left(\mathrm{a}_{\mathrm{c}} \mathrm{a}_{\mathrm{o}}\right)\right)=4882 / \mathrm{T}+8.65 \mathrm{~kJ} / \mathrm{mol}^{7)} \ldots
$$

Where $P_{c o}$ is the partial pressure of carbon monoxide in the atmosphere, and the activities $a_{c}$ and $a_{o}$ are taken equivalent to $\mathrm{wt} \% \underline{\mathrm{C}}$ and $\mathrm{wt} \% \underline{\mathrm{O}}$, respectively, at low solute concentrations. Similarly, ladle degassing relies on the formation of $\mathrm{CO}$ bubbles (by vacuum or by blowing inert argon gas) to provide efficient stirring for impurity removal, ${ }^{8,9)}$ while the production of rimming steel ingots depends upon the nucleation of $\mathrm{CO}$ bubbles at the advancing solid-liquid interface. ${ }^{10,11)}$ The direct smelting processes including HIsmelt, COREX, DIOS, AISI direct steelmaking and Romelt processes ${ }^{12)}$ are also heavily influenced by the $\mathrm{C}-\mathrm{O}$ reaction as gases such as $\mathrm{CO}, \mathrm{H}_{2}, \mathrm{O}_{2}$, and $\mathrm{CO}_{2}$ are injected into liquid melts in these processes. ${ }^{13)}$ In the Argon

\footnotetext{
* Corresponding author: E-mail: zhuangzhuang.liu@kuleuven.be
}

Oxygen Decarburization (AOD) practice, the $\mathrm{Ar} / \mathrm{O}_{2}$ ratio in the injected gas is carefully controlled to increase with time. ${ }^{14)}$ The $\mathrm{CO}$ partial pressure in the $\mathrm{Ar}-\mathrm{O}_{2}$ gas bubble can increase with time due to the $\mathrm{C}-\mathrm{O}$ reaction and an enhanced $\mathrm{CO}$ partial pressure can lead to the $\mathrm{CO}$ absorption in the liquid steel during bubble rising. Thus, a quantitative understanding of the $\mathrm{CO}$ absorption is required. Moreover, mathematical modelling and numerical simulation have become a powerful tool to understand and control metallurgical processes. ${ }^{15-21)}$ A comprehensive understanding of the $\mathrm{C}-\mathrm{O}$ reaction is of great importance for the accurate simulation of industrial processes like the BOF operation. ${ }^{22-27)}$ Due to its importance, many efforts have been paid to understand the rate and mechanisms of this reaction (Eq. (1)). Different experimental methods, such as Sieverts' test, ${ }^{28,29)}$ levitated droplet, $^{30-32)}$ isotope exchange technique ${ }^{33)}$ and vacuum degassing, ${ }^{34)}$ have been employed in $\mathrm{CO}$ absorption and/or desorption studies. However, the results are not always consistent and even contradict each other, particularly in the rate-limit step of the $\mathrm{C}-\mathrm{O}$ reaction, i.e. carbon and/or oxygen diffusion in the liquid steel, ${ }^{28,29,34-38)}$ gaseous diffusion in the gas phase, ${ }^{30,31,39-45)}$ and interfacial reactions. ${ }^{33,46)}$ Moreover, in the literature it is constantly assumed that the $\mathrm{CO}$ absorption and desorption process are symmetrical, meaning the rate-limiting step of the two reactions is the same and the overall reaction rate is equivalent under the same experimental conditions. However, King et al. ${ }^{37)}$ observed that for low carbon steel $(\sim 0.05 \mathrm{wt} \% \mathrm{C})$ the $\mathrm{CO}$ desorption rate was anomalously slower than the absorption rate. The difference in the mechanism of the two processes (CO absorption and desorption) is not yet clearly understood. Therefore, in order to supply data and knowledge for 
a fundamental understanding of the reaction mechanisms, a literature review on the carbon monoxide absorption into and desorption from a liquid steel is conducted.

\section{Literature Review}

\subsection{Methodology}

In spite of many efforts, no consensus has been reached concerning the mechanism of CO-liquid iron/steel reaction. Some conclusions with respect to the rate-limiting step of the reaction are even contradictory. It is found in literature that the experimental set-up used in gas-metal reaction study varies with different researchers. Hence, it is meaningful to summarize these techniques and examine the advantages and limitations of each method.

\subsubsection{Furnace Melting}

One of the most widely used equipment in the study of gas-melt reaction is the high temperature furnace. As shown in the work of Suzuki and Mori, ${ }^{34)}$ an induction melting furnace was used to measure the $\mathrm{CO}$ degassing rate from molten iron (Fig. 1). A magnesia crucible was placed in a quartz reaction tube and heated by high-frequency induction coils. $400 \mathrm{~g}$ of electrolytic iron was melted in the magnesia crucible in an argon atmosphere. Once the temperature was stabilized $\left(1550-1677^{\circ} \mathrm{C}\right.$ in this case), initial carbon and oxygen were regulated to be respectively $0.01-0.1 \mathrm{wt} \% \underline{\mathrm{C}}$ and $0.01-0.09 \mathrm{wt} \% \underline{\mathrm{O}}$ by blowing a $\mathrm{CO}-\mathrm{CO}_{2}$ gas mixture. After equilibrium was attained, the $\mathrm{CO}$ desorption process was started by replacing the furnace atmosphere with Ar, followed by sampling with silica tubes. The changes of carbon and oxygen concentrations during the $\mathrm{CO}$ degassing process were obtained by the LECO analysis of the steel samples with carbon and oxygen.

Some researchers also used the furnace melting method but with different experimental conditions. Rathke and Tarby ${ }^{47)}$ studied the influence of reduced CO pressure on

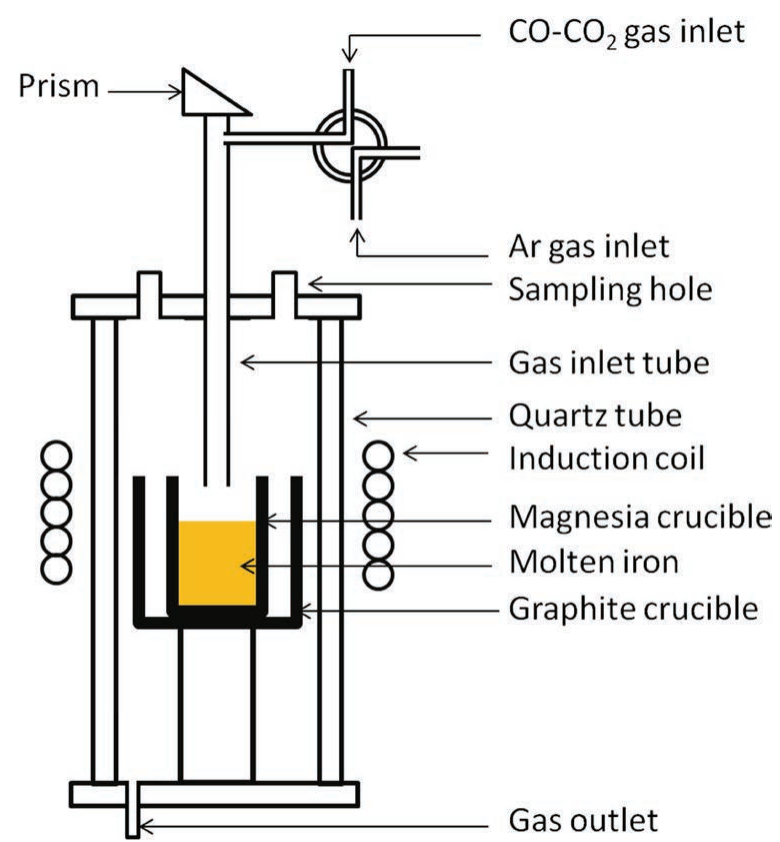

Fig. 1. Experimental set-up for $\mathrm{CO}$ desorption from liquid iron. ${ }^{34)}$ (Online version in color.) the $\underline{\mathrm{C}}-\underline{\mathrm{O}}$ reaction in an $\mathrm{Fe}-0.21$ wt $\% \underline{\mathrm{C}}$ melt in a precision casting vacuum system (induction melting). This test simulates the industrial vacuum degassing practice, where liquid steel is suddenly exposed to a reduced pressure for a short duration while the CO desorption occurs. The molten bath was sampled by pouring the liquid metal into a block mold as a function of time during equilibrium (at a specific CO pressure). Bui et al. ${ }^{48)}$ ran a similar test by evacuating the furnace chamber to $\sim 0.79$ atm with a vacuum pump and found the carbon content decreased from $2.615 \mathrm{wt} . \%$ (weight percentage) to $0.016 \mathrm{wt} . \%$ in $120 \mathrm{~min}$ at $1500^{\circ} \mathrm{C}$.

The furnace melting set-up is easy to access and flexible in terms of sample size, sample composition, temperature and initial gas composition. However, during the experiment, the gas flow rate is set as a fixed value. As shown in Suzuki and Mori's experiment, gas flow rate was optimized as $1500 \mathrm{~mL} / \mathrm{min}$ (in Ito's furnace melting experiment, ${ }^{31}$ ) the flow rate was $2000 \mathrm{~mL} / \mathrm{min}$ ) until the reaction rate was independent of the gas blowing rate. This means that the gas phase diffusion such as $\mathrm{O}_{2} / \mathrm{CO} / \mathrm{CO}_{2}$ mass transfer from the gas boundary layer to the gas-melt interface is excluded from the discussion of the rate-limiting step. In this context, special attention in most furnace melting experiments was paid to the liquid phase diffusion.

\subsubsection{Sieverts-type Apparatus}

The Sieverts-type apparatus, also known as volumetric technique, has been widely used to measure gas sorption (e.g. hydrogen) on a material (e.g. hydrogen storage material). ${ }^{5,49)}$ The principle is to measure the variations in the volume of a gaseous system while keeping the pressure constant. $^{50)}$

Solar and Guthrie ${ }^{29)}$ employed the Sieverts-type method to investigate the $\mathrm{CO}$ absorption kinetics into liquid iron with a CO pressure ranging from 0.1 to $1.5 \mathrm{~atm}$ at $1600^{\circ} \mathrm{C}$. A 4 $\mathrm{cm}$ long rod iron (diameter $=2 \mathrm{~cm}$ ) sample was introduced into an alumina tube with a closed end. The diffusion cell was placed in the measuring system, which was evacuated and flushed with pure argon (see Fig. 2). Subsequently, the cell was lowered into the furnace, heated up to the test temperature $\left(1580-1700^{\circ} \mathrm{C}\right.$ in this case), and then evacuated, maintaining the low pressure for 3 hours by closing stopcock S5, as illustrated in Fig. 2. The vacuum in the diffusion cell is preserved, while the left part of the apparatus was filled with CO. The initial carbon and oxygen concentrations in the metal bulk are homogenous and equal to $C_{C}^{\infty}$ and $C_{O}^{\infty}$, respectively. At time $\mathrm{t}=0$, stopcock S8 was opened. The evacuated space (on top of the melt) is then quickly filled with $\mathrm{CO}$ at pressure $\mathrm{P}(0.1-1.5 \mathrm{~atm}$ at $1600^{\circ} \mathrm{C}$ ). It was assumed that the dissociation (CO absorption into liquid steel) reaction $\mathrm{CO}=\underline{\mathrm{C}}+\underline{\mathrm{O}}$ was instantaneous at the melt-gas interface. $C_{C}^{*}$ and $C_{O}^{*}$ (carbon and oxygen concentration at gas-melt interface) then immediately reached the equilibrium level so that $C_{C}^{*} \cdot C_{O}^{*}=K P^{0}$ ( $K$ : reaction constant). 10 seconds later, the differential pressure transducer shunt S4 was closed. As CO is absorbed by molten iron, the absorption rate is measured by monitoring the pressure drop in the gas phase at constant volume using the differential pressure transducer (measure the differential pressure change between its two sides) or monitoring the volume change while fixing the pressure value. Once the 


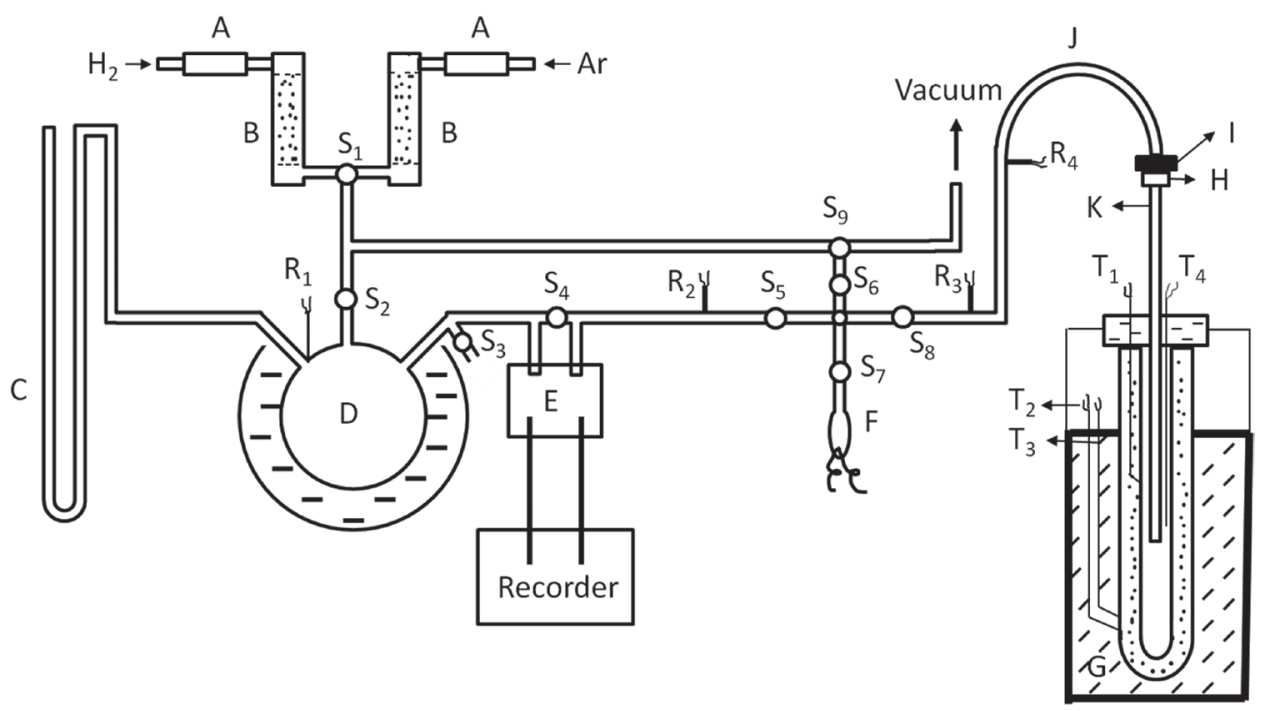

Fig. 2. Schematic of Sieverts-type apparatus. A - DEOXO catalytic gas purifier, B - DRIERITE tower; C - mercury manometer; D - reference volume; E - differential pressure transducer; F - absorption micro-burette (in volume method apparatus only); G - molybdenum furnace; H - leveling mechanisms; I - O-ring connector; J polyethylene tubing; $\mathrm{K}$ - diffusion cell assembly; R1, R2, R3 - water-jacket thermistors; R4 - Gas phase thermistors; S1, S2, .. S9 - high-vacuum stopcocks; T1 - travelling thermocouple; T2, T3, T4 - control thermocouples. ${ }^{50)}$

absorption experiments were completed for a given sample, the crucible assembly was taken out of the furnace and quenched in cold water. The absorption kinetics of $\mathrm{CO}$ by stagnant liquid iron was then explained in terms of a simplified mass transfer model involving simultaneous diffusion of the dissolved carbon and oxygen.

Parlee et $a l^{36)}$, examined the $\mathrm{CO}$ absorption and desorption rates into/from the inductively stirred melts with a Sieverts-type apparatus. The experimental procedure consisted of equilibrating the liquid steel with an initial $\mathrm{CO}$ pressure and then rapidly altering the pressure to a required value. The pressure was kept constant at this value by changing the volume of the system. To estimate the rate of $\mathrm{CO}$ desorption from Fe-O-0.15-4.4 wt $\% \underline{\mathrm{C}}$ melt and the rate of the reverse reaction (i.e. $\mathrm{CO}$ absorption into the melt), the volume changes as a function of time was recorded. Similarly, King et $a l^{37)}$ used the Sieverts' type equipment in studying the $\mathrm{CO}$-iron melt reaction. However, instead of using an inductively stirred melt, they performed the experiment in a naturally-convection iron melt.

Although the measuring system is complicated with respect to the furnace melting method, one of the important features of the Sieverts-type set-up is to exactly quantify the pressure/volume change of the gas with time, i.e., the quantity of the absorbed CO by liquid alloy with time. Hence, the kinetic data of carbon and oxygen diffusion in liquid phase can be determined.

\subsubsection{Levitated Droplet Experiment}

In the experiment with the Sieverts type apparatus or the furnace melting set-up, the reaction between refractory/crucible materials and liquid alloys was found to significantly influence the results. For example, in Parlee et al.'s experiment ${ }^{36}$ ) with a Sieverts' type apparatus, the reaction between the alumina crucible and carbon in liquid iron was observed in the high carbon-containing sample, as shown in Eq. (3).

$$
1 / 3 \mathrm{Al}_{2} \mathrm{O}_{3}(\text { crucible })+\underline{\mathrm{C}}=2 / 3 \underline{\mathrm{Al}}+\mathrm{CO}(\mathrm{g})
$$

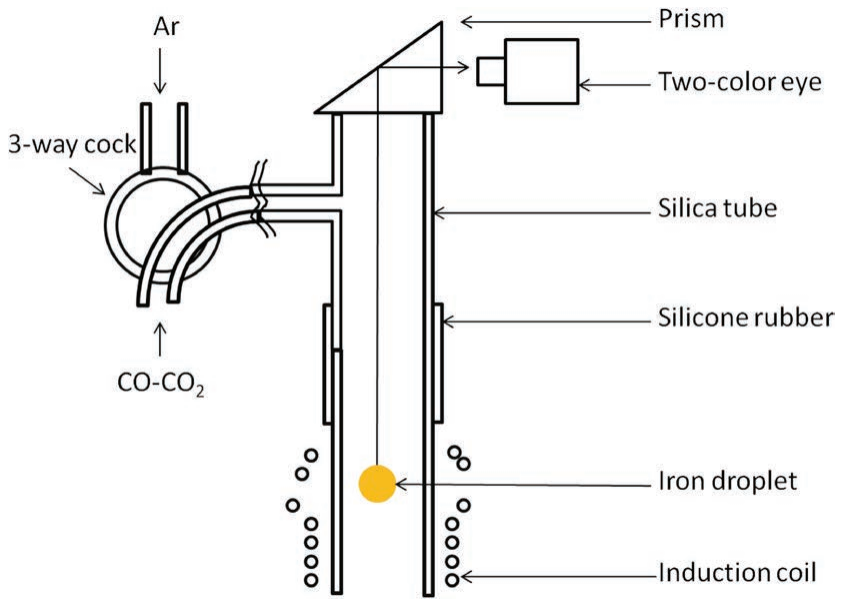

Fig. 3. Schematic of levitated method. ${ }^{41)}$ (Online version in color.)

This reaction markedly increases the $\mathrm{CO}$ desorption rate. Similarly, Ito et al. ${ }^{31)}$ measured the CO degassing/desorption rate from liquid iron by crucible melting. They found that the change in the oxygen/carbon concentration ratio during degassing is lower than the stoichiometrical relations. This was explained by metal/crucible $(\mathrm{MgO})$ interface reactions: i.e. crucible corrosion leads to an increase in oxygen content in the liquid iron (see Eq. (4)).

$$
\mathrm{MgO}_{(\mathrm{s})}=\underline{\mathrm{Mg}}+\underline{\mathrm{O}}
$$

In order to eliminate the effect of crucible/steel interaction, several researchers ${ }^{30,39,51)}$ employed the levitated droplet method in the gas-melt study. Ito et al. ${ }^{41)}$ measured the rate of carbon and oxygen transfer between $\mathrm{CO}-\mathrm{CO}_{2}$ mixtures and iron using the levitated droplet method, as shown in Fig. 3. An iron-droplet (electrolytic iron, $\mathrm{Fe}>$ 99.97\%) was melted in a silicon tube flushed with pure Ar. The sample was heated by an induction heating coil. After reaching the desired temperature $\left(1870-2070^{\circ} \mathrm{C}\right)$, the atmosphere was quickly replaced by a $\mathrm{CO}-\mathrm{CO}_{2}$ mixture 
with a specific composition $\left(\mathrm{CO}_{2}: 0-5\right.$ vol.\%) at various flow rates $(270-3000 \mathrm{~mL} / \mathrm{min})$. Once reaching the scheduled reaction time, the furnace power was switched off and a water-cooled copper mold was raised up to quench the liquid droplet. The carbon and oxygen content of the quenched sample were further analyzed to determine the evolution of carbon and oxygen concentration with time at various conditions (temperature, gas composition and flow rate), corresponding to the $\mathrm{CO}$ absorption rate.

Baker et $a .^{39)}$ measured the decarburization of levitated $\mathrm{Fe}-0$ to $5.5 \mathrm{wt} \% \underline{\mathrm{C}}$ alloy droplets at $1660^{\circ} \mathrm{C}$ flushed by 1 , 10 , and $100 \% \mathrm{O}_{2}-\mathrm{He}$ gas mixtures. An equation was derived to predict the rate of oxygen diffusion to the droplet through the gas boundary layer, as shown in Eq. (5).

$$
N_{O_{2}}=\frac{D\left(O_{2}-X\right)_{f} P \overline{N u}}{R T_{f} d_{p}} y O_{2}
$$

where $N_{O_{2}}$ is the flux oxygen $\left(\mathrm{mol} \cdot \mathrm{cm}^{-2} \mathrm{~s}^{-1}\right), D$ is the gas diffusion coefficient $\left(\mathrm{cm}^{2} \mathrm{~s}^{-1}\right), T$ is the temperature of gas film (K), $P$ is the total pressure (atm), $R$ is the gas constant $\left(82.06 \mathrm{~cm}^{3} \mathrm{~atm} \cdot \mathrm{k}^{-1} \cdot \mathrm{mol}^{-1}\right), d_{p}$ is the spherical diameter (cm), $N u$ ' is the Nusselt number for mass transfer based on the total surface of a sphere. $X$ is the inert component in the gas mixture.

Distin et $a l .{ }^{30)}$ conducted a similar levitation experiment by blowing $\mathrm{O}_{2}, \mathrm{CO}_{2}, \mathrm{O}_{2}+\mathrm{H}_{2} \mathrm{O}$, and $\mathrm{H}_{2} \mathrm{O}$ gas mixtures and found that the decarburization rate increased significantly at more elevated gas flow rates.

Simento et $a l^{42-44)}$ systematically investigated the decarburization kinetics using the levitated droplet method, by blowing inert gas $\left(\mathrm{N}_{2}\right.$ and/or $\mathrm{He}$ ) with $\mathrm{O}_{2}, \mathrm{CO}_{2}, \mathrm{O}_{2}+\mathrm{CO}_{2}$, and $\mathrm{O}_{2}+\mathrm{H}_{2} \mathrm{O}$, respectively. The key findings are: (1) the decarburization rate with $10 \%$ oxygen at $1450^{\circ} \mathrm{C}$ is limited by the transport of oxygen in the bulk gas to the melt surface; (2) the experiment with $\mathrm{CO}_{2}$ at $1450^{\circ} \mathrm{C}$ shows that the decarburization is jointly controlled by gas phase mass transport and dissociative chemisorption of $\mathrm{CO}_{2}$; (3) for the decarburization with $\mathrm{O}_{2}+\mathrm{CO}_{2}$, the rate is limited by the $\mathrm{O}_{2}$ and $\mathrm{CO}_{2}$ transport in the gas phase with additional resistance from the interfacial reaction kinetics of $\mathrm{CO}_{2}$; (4) in the case of simultaneous decarburization by $\mathrm{O}_{2}+\mathrm{H}_{2} \mathrm{O}$, the basic mechanism of decarburization is similar to that of $\mathrm{O}_{2}+\mathrm{CO}_{2}$, but the reaction between $\mathrm{O}_{2}$ and $\mathrm{CO}$ to produce $\mathrm{CO}_{2}$ occurs in the vicinity of the interface, lowering the decarburization rate.

Widlund et $a l^{45}$ ) investigated the decarburization of $\mathrm{Fe}-4 \% \mathrm{C}$ alloys containing silicon in the 0.3 to $0.7 \%$ range under a $\mathrm{He}+\mathrm{O}_{2}$ gas mixture. The results show that at high carbon content $(>0.5 \%)$, the decarburization rate is not dependent on the carbon concentration in the liquid steel. Instead, the decarburization rate is controlled by the $\mathrm{O}_{2}$ partial pressure in the gas mixture $(\mathrm{Si}=0.37-0.71 \%, \mathrm{~T}=$ $1400-1700^{\circ} \mathrm{C}$ ), indicating a gas mass transfer-controlled mechanism in this experimental condition $(\mathrm{C}>0.5 \%, \mathrm{Si}=$ $0.37-0.71 \%, \mathrm{~T}=1400-1700^{\circ} \mathrm{C}$ ).

It is clear that in the levitated droplet experiment, no crucible contamination/corrosion occurs. Additionally, both gas and liquid phase diffusion can be taken into account while analyzing the rate-limiting step.

\subsubsection{Isotope Exchange Technique}

In the discussion of the $\mathrm{CO}$ absorption and desorption, it is constantly assumed that the chemical reaction at the gas-melt interface is instantaneous. To quantify the interfacial reaction rate, the isotope exchange method was used by a number of researchers. ${ }^{33,46,52)}$ The measurement is made at chemical equilibrium, so that the isotope reaction is not influenced by liquid phase mass transfer. Kim et al. ${ }^{46)}$ used an isotope exchange technique to investigate the kinetics of $\mathrm{CO}$ dissociation/absorption into the molten iron. As shown in Fig. 4, a graphite crucible serving as both heating element and protective crucible was placed in the induction furnace. An alumina crucible with iron specimen was introduced into the graphite crucible. The furnace was heated up to the desired temperature $\left(1100-1500^{\circ} \mathrm{C}\right)$ in an argon atmosphere. After temperature stabilization, the argon gas was replaced by a $\mathrm{CO}+{ }^{13} \mathrm{CO}$ gas mixture. The distance between the end of the lance (for gas injection) and the crucible was minimized to prevent the leakage of reaction gases. The exit gas composition was measured by a quadruple mass spectrometer. In the preliminary test prior to the measurement, the gas flow rate was increased above the critical value in such a way that gas phase mass transfer could be excluded from the rate-limiting steps. Thus, the $\mathrm{CO} /$ melt interfacial reaction rate (on the molten iron surface) at different temperatures could be measured.

To study chemical kinetics of $\mathrm{CO}$ on liquid iron alloys, Fruehan and Antolin $^{33)}$ have also employed the isotope exchange technique by using a double isotope of $\mathrm{CO}$ containing $\mathrm{C}^{13}$ and $\mathrm{O}^{18}\left(\mathrm{C}^{13} \mathrm{O}^{18}\right)$. Taking into account the overall isotope exchange reaction for $\mathrm{C}^{13} \mathrm{O}^{18}$ dissociation,

$$
\mathrm{C}^{13} \mathrm{O}^{18}+\mathrm{C}^{12} \mathrm{O}^{16}=\mathrm{C}^{13} \mathrm{O}^{16}+\mathrm{C}^{12} \mathrm{O}^{18}
$$

the rate constant, $\mathrm{k}$, for the reaction can be derived as Eq. (6).

$$
k=-\frac{\vec{V}}{A} \ln \left\{\frac{F_{31}^{0}-F_{31}^{e q}}{F_{31}^{i}-F_{31}^{e q}}\right\}
$$

Where $\vec{V}$ is the gas flow rate, $A$ is the surface area of liquid iron alloys, $F_{31}$ is the fraction of the $\mathrm{C}^{13} \mathrm{O}^{18}$ isotope in the gas phase. The superscript $0, i$ and eq. refer to the moment, respectively, at the start of experiment, time $i$ and

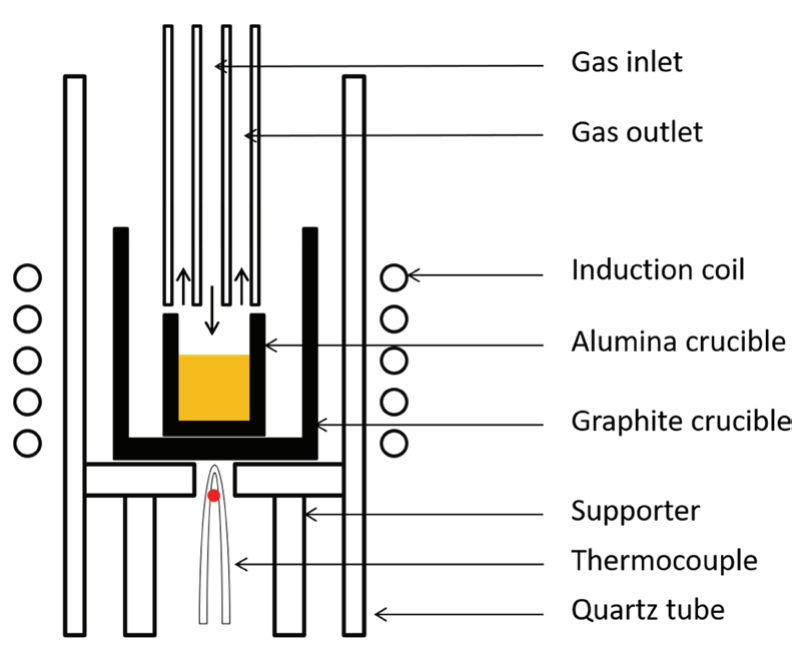

Fig. 4. Schematic diagram of isotope exchage technique. ${ }^{46}$ (Online version in color.) 
the equilibrium state. According to the experiment, the reaction rate constant is estimated to be $1.5 \times 10^{-5} \mathrm{~mol} \cdot \mathrm{cm}^{-2} \mathrm{~s}^{-1}$ at $1600^{\circ} \mathrm{C}$.

Fan et $a l .{ }^{53)}$ studied the decarburization rate of $\mathrm{Fe}-\mathrm{C}$ melts with a $\mathrm{CO}_{2}-\mathrm{O}_{2}$ mixture by employing the isotope tracing technique. Their results indicate that the utilization rate of $\mathrm{CO}_{2}$ exceeds $97 \%$. However, only approximately $52 \%$ of the oxygen reacted with $\mathrm{C}$ to form $\mathrm{CO}$ and $17 \%$ of the oxygen reacted to form $\mathrm{CO}_{2}$. The rest of oxygen (31\%) was reacted during post combustion. Fan et al.'s work focuses on the source of $\mathrm{CO}_{2}$ formed in the decarburization, while no analysis on the mechanism of the $\mathrm{C}-\mathrm{O}$ or $\mathrm{C}-\mathrm{CO}_{2}$ reaction was performed.

\subsection{Kinetics of $\mathrm{CO}$ Absorption and Desorption}

Kinetic studies, particularly the determination of their rate-limit step, are critical in metallurgical processes involving $\mathrm{CO}$ absorption and desorption, such as $\mathrm{CO}$ degassing, carburization by $\mathrm{CO}$, and decarburization by ejecting oxygen-inert gas mixture or $\mathrm{CO}_{2}$ into molten steel/iron. Although the controlling step of the reaction ( $\mathrm{CO}$ absorption and desorption) has been discussed in many studies, no consensus has been achieved yet. According to literature, the possible rate-limiting step for $\mathrm{CO}$ absorption and desorption includes (a) mass transfer in the liquid phase; (b) mass transfer in the gas phase; (c) chemical reaction at the interface; and (d) bubble nucleation in the liquid phase.

\subsubsection{Oxygen and/or Carbon Mass Transfer in Liquid Metal Phase}

One of the earliest investigations was made by Parlee et $a l .{ }^{36)}$ using a Sieverts' type apparatus. As seen in Fig. 5, the rate constant of $\mathrm{C}-\mathrm{O}$ reaction in the investigated system (Fe-0.2 to $4.5 \mathrm{wt} \% \underline{\mathrm{C}}$ ) is almost constant when the carbon content is in excess of $0.2 \mathrm{wt} \%$. It was concluded that the reaction rate was primarily controlled by oxygen diffusion in the metal at $\underline{\mathrm{C}}>0.2 \mathrm{wt} \%$.

King et $a l .{ }^{37)}$ studied the absorption and desorption of $\mathrm{CO}$ in naturally-convecting iron melts. They found that the absorption rate of $\mathrm{CO}$ for all carbon contents, and the $\mathrm{CO}$ desorption rate for medium carbon content $(\sim 0.2 \mathrm{wt} \% \underline{\mathrm{C}})$, were controlled by the mass transport of oxygen in liquid steel. However, they observed that the $\mathrm{CO}$ desorption rate from low carbon steel $(\sim 0.05 \mathrm{wt} \% \underline{\mathrm{C}})$ were anomalously

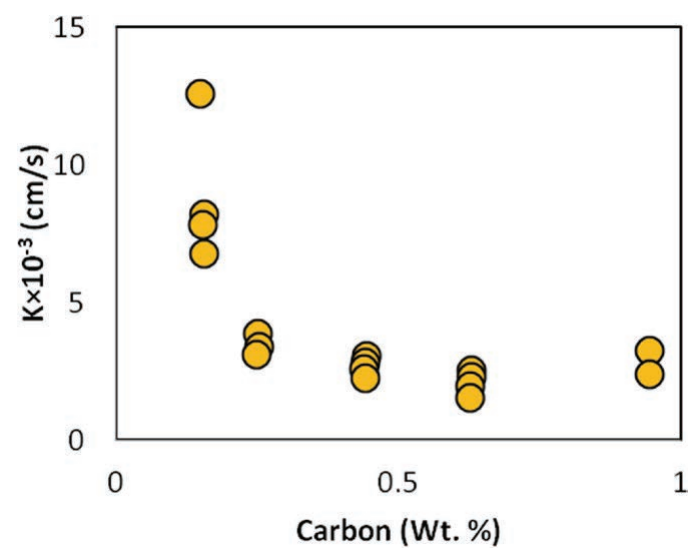

Fig. 5. Effect of carbon content (wt.\%) on rate constants at $1630^{\circ} \mathrm{C}^{36)}$ (Online version in color.) low. The low CO desorption rate was attributed to a slow surface reaction as the available sites are limited by strong adsorption of oxygen.

Solar et al. ${ }^{29)}$ performed a Sieverts' type measurement for $\mathrm{CO}$ absorption in stagnant iron, where vacuum was initially maintained at the top of the melt and then the evacuated space is filled with $\mathrm{CO}$ gas. The absorption rate of $\mathrm{CO}$ is recorded by the pressure drop in the gas phase at a constant volume. It was found that the pressure drop $(\Delta P)$ can be expressed as a function of root time (i.e. $\Delta P=\alpha \sqrt{t}$ ). Mass transfer equations developed to describe the absorption were adapted to define an 'apparent diffusion coefficient' of carbon monoxide by essentially taking both carbon and oxygen diffusivity in the liquid phase into account. Over the temperature range from 1570 to $1700^{\circ} \mathrm{C}$, the apparent diffusion coefficient of $\mathrm{CO}$ at 1 atm in liquid iron (initially containing approximately $80 \mathrm{ppm}$ of both carbon and oxygen) was given by:

$$
D_{C O}=3.51 \cdot 10^{-3} \exp -\frac{13872 \pm 8455}{R T}
$$

The measured $D_{c o}$ values was $9.8 \times 10^{-5} \mathrm{~cm}^{2} \mathrm{~s}^{-1}$ on average, while carbon and oxygen diffusivities were calculated to be $41.2 \times 10^{-5}$ and $5.2 \times 10^{-5} \mathrm{~cm}^{2} \mathrm{~s}^{-1}$, respectively.

Schenck et al. ${ }^{28,38)}$ and Knuppel et al. ${ }^{54)}$ measured CO desorption rates from liquid iron under reduced pressure. The influence of the experimental parameters such as temperature, chromium content and surface-active elements on the desorption rate of $\mathrm{CO}$ were determined. ${ }^{28)}$ It was concluded that sulfur had no effect on the $\mathrm{CO}$ desorption rate. They also reported that the chemical reaction rate in the $\mathrm{CO}$ desorption process was very fast and that the overall $\mathrm{CO}$ desorption rate was controlled by liquid phase mass transfer. The CO desorption rate was significantly affected by carbon and oxygen concentrations in the liquid iron. In case of low initial carbon contents, the generated amount of $\mathrm{CO}$ gas increases linearly with initial carbon content. In case of high carbon content, however, the released $\mathrm{CO}$ increases with the reciprocal value of the initial carbon content. The mass transfer coefficient of oxygen in the liquid iron was derived as Eq. (8):

$$
k_{O}=18.5 \exp \left(-\frac{20200}{R T}\right)
$$

At $1600^{\circ} \mathrm{C}$, effective diffusion coefficient of oxygen $\left(D_{o}\right)$ in the liquid iron was estimated to be $22 \times 10^{-5} \mathrm{~cm}^{2} \mathrm{~s}^{-1}$. This value is in the same order of magnitude of the estimation by Solar et al. ${ }^{29)}$

Suzuki et al. ${ }^{34)}$ studied the kinetics of CO desorption by measuring concentration changes of carbon and oxygen with reaction time in an inductively stirred bath. The experimental data highlight that: (a) for carbon higher than $0.03 \mathrm{wt} \%$, the rate is controlled by oxygen mass transfer in the metal only; the value of $k_{o}$ (mass transfer coefficient of oxygen in liquid iron) is approximately $0.035 \mathrm{~cm} \mathrm{~s}^{-1}$; (b) for oxygen higher than $0.06 \mathrm{wt} \%$, the rate is controlled by mass transfer of carbon, and the value of $k_{c}$ (mass transfer coefficient of carbon in liquid iron) is approximately $0.051 \mathrm{~cm} \mathrm{~s}^{-1}$; (c) the changeover from oxygen mass transfer control to carbon mass transfer control occurs at a ratio of $C_{c} / \mathrm{C}_{o}=$ 0.69, as shown in Fig. 6; (d) mixed mass transport control 


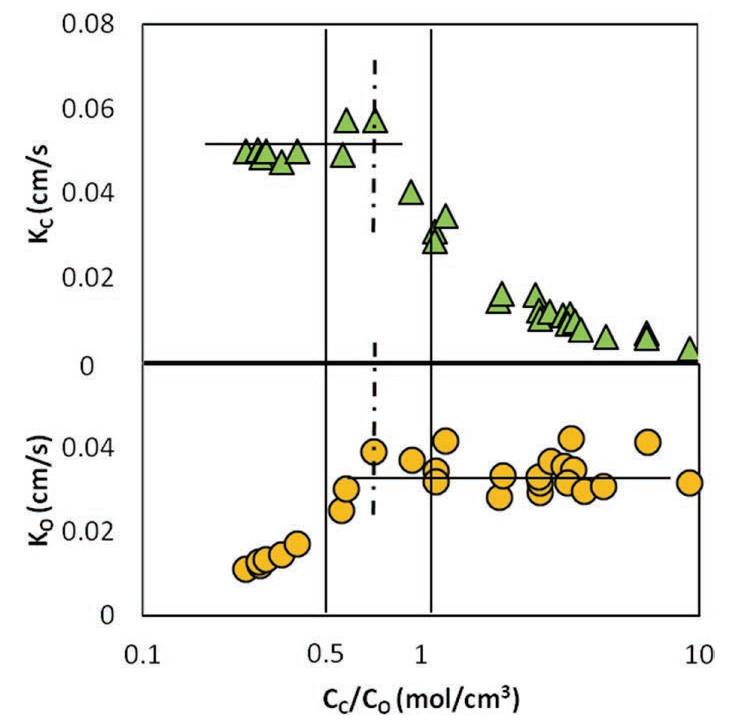

Fig. 6. Mass transfer coefficients of carbon and oxygen in iron with the ratio of carbon and oxygen contents $\left(\mathrm{mol} / \mathrm{cm}^{3}\right){ }^{34)}$ (Online version in color.)

and mixed control (chemical reaction plus mass transfer in liquid phase), when assumed as the rate-limiting step, do not fit with the observed results. The experimental data in Fig. 6 also show that for $C_{c} / \mathrm{C}_{o}<0.69$, the $k_{c}$ value is constant and for $C_{c} / \mathrm{C}_{o}>0.69$, the $k_{o}$ value is constant. The former implies that the reaction is controlled by mass transport of oxygen, while the latter suggests mass transport of carbon controls the reaction rate. Hence, the overall kinetics of $\mathrm{CO}$ desorption during argon blowing could be determined by initial carbon or oxygen content and the mass transfer coefficient $\left(k_{c}, k_{o}\right)$. However, as commented by Ito et al., ${ }^{31)}$ the increased CO desorption in Suzuki et al.'s experiment was due to the reaction between refractory materials $(\mathrm{MgO}$ crucible) and molten iron. It is suggested that the crucible melting method is not suitable for the kinetics study of $\mathrm{CO}$ degassing, provided that the rate of crucible-melt reaction is not quantitatively determined. Ito et $a l .^{31,40)}$ measured the rates of $\mathrm{CO}$ degassing for liquid iron containing 0.025 $0.095 \mathrm{wt} \% \underline{\mathrm{C}}$ and $0.03-0.09 \mathrm{wt} \% \underline{\mathrm{O}}$ by using the levitation method. The $\mathrm{CO}$ desorption proceeds stoichiometrically, as shown in $\underline{\mathrm{C}}+\underline{\mathrm{O}}=\mathrm{CO}$, until carbon or oxygen is depleted, indicating a carbon and/or oxygen mass transfer-controlling step in the liquid phase. Wang et al. ${ }^{35)}$ blew $\mathrm{O}_{2}-\mathrm{CO}_{2}$ gas mixtures into the $\mathrm{Fe}-\mathrm{Cr}-\mathrm{C}$ melts and found that the decarburization is controlled by the mass transfer in the liquid iron. Kim et al $^{73)}$ calculated the forward and backward reaction rate constant of the $\mathrm{C}-\mathrm{O}$ reaction (Eq. (1)), based on the experimental data reported by Dancy ${ }^{55)}$ and Lloyd et al ${ }^{56)}$ They obtained the following equations:

Forward reaction rate constant,

$k=1.33 \times 10^{8} \exp (-250000 / \mathrm{RT}), \mathrm{mol} /\left(\mathrm{m}^{2} \mathrm{~s}\right)$

Backward reaction rate constant,

$k=2.40 \times 10^{11} \exp (-277000 / \mathrm{RT}), \mathrm{mol} /\left(\mathrm{m}^{2} \mathrm{~s}\right)$

\subsubsection{Mass Transfer in Gas Phase}

Baker et $a l .{ }^{39)}$ studied the decarburization of a levitated $\mathrm{Fe}-0$ to $5 \mathrm{wt} \% \underline{\mathrm{C}}$ alloy droplet flushed by $\mathrm{O}_{2}-\mathrm{He}$ gas mix- tures with various $\mathrm{O}_{2}$ fractions $(1,10$ and $100 \%)$. It was found that for high carbon concentrations, the decarburization rate of the levitated drop at $1660^{\circ} \mathrm{C}$ was completely controlled by the rate of $\mathrm{O}_{2}$ diffusion to the droplet through the gas boundary layer. For low carbon content $\mathrm{Fe}-\mathrm{C}$ alloy, where $\mathrm{CO}$ nucleates homogeneously in the droplet, the decarburization decreased with carbon content of the liquid steel. In this case, local carbon diffusion control became significant.

Distin et al. ${ }^{30)}$ conducted a similar levitation experiment by blowing $\mathrm{O}_{2}, \mathrm{CO}_{2}, \mathrm{O}_{2}+\mathrm{H}_{2} \mathrm{O}$, and $\mathrm{H}_{2} \mathrm{O}$ gas mixtures. The measured decarburization rates were significantly influenced by the oxygen gas flow rate, suggesting that the reactions were controlled by the mass transfer in the gas phase. They also estimated the rate of oxygen absorption to the liquid droplet during the tests, and the oxygen mass transfer coefficient, $k_{o}$, of 0.002 to $0.003 \mathrm{~cm} \mathrm{~s}^{-1}$ was determined.

Whiteway et al. $^{57)}$ studied the kinetics of decarburization of iron melts (1.3 to $1.4 \mathrm{wt} \% \underline{\mathrm{C}})$ by blowing argon-oxygen gas mixtures $\left(0.1\right.$ to 1.2 vol. $\left.\% \mathrm{O}_{2}\right)$. They concluded that under their experimental conditions the decarburization process was controlled by the diffusion of oxygen in the gas phase. In the experiment of Ito et al., ${ }^{40)}$ using the levitation melting technique, it was found that in the initial stage the $\mathrm{CO}$ absorption is not dependent on the composition gas mixture, indicating the absorption rate is controlled by the mass transfer in the bulk melt. At the later stage, the $\mathrm{CO}$ and $\mathrm{CO}_{2}$ diffusion in the gas phase tends to control the absorption and desorption process.

\subsubsection{Chemical Reaction}

Fruehan et al. ${ }^{33)}$ employed the isotope exchange technique to study the chemical kinetics of $\mathrm{CO}$ on liquid iron by using a double isotope of $\mathrm{CO}$ containing $\mathrm{C}^{13}$ and $\mathrm{O}^{18}\left(\mathrm{C}^{13} \mathrm{O}^{18}\right)$. The reaction is shown in Eq. (5). As seen in Fig. 7, at $1600^{\circ} \mathrm{C}$, the isotope exchange rate for $\mathrm{C}^{13} \mathrm{O}^{18}$ in normal $\mathrm{CO}$ on liquid iron was not a strong function of sulfur content up to 0.43 $\mathrm{wt} \%$, but a function of gas flow rate, implying that the rate is controlled by gas phase mass transfer. At low temperature $\left(1250^{\circ} \mathrm{C}\right)$ and $\underline{\mathrm{S}}>0.015 \mathrm{wt} \%$, the reaction rate may be controlled by mixed controlling steps, i.e. gas phase mass transfer and chemical kinetics. Under this condition, the reaction rate constant is estimated to be $1.5 \times 10^{-5} \mathrm{~mol} \cdot \mathrm{cm}^{-2} \mathrm{~s}^{-1}$. However, Sasaki et al. ${ }^{52)}$ re-examined the interfacial reaction of $\mathrm{CO}$ with liquid iron by using the isotope exchange technique as well. They concluded that the rate constant of the $\mathrm{CO}(\mathrm{g}) \rightarrow \mathrm{C}$ (ads) $+\mathrm{O}$ (ads) reaction, as determined by Fruehan et al., ${ }^{33)}$ was too small $\left(5.4 \times 10^{-5} \mathrm{~mol} \cdot \mathrm{cm}^{-2} \mathrm{~s}^{-1}\right.$ for iron containing $0.1 \mathrm{wt} . \% \mathrm{~S}$ ) based on their theoretical calculations. They proposed that the small value was attributed to the fact that the melt surface was partially covered by sulfur in Fruehan et al.'s experiment, while the rate constant should be estimated according to a bare surface. The presence of sulfur blocked the $\mathrm{CO}$ adsorption sites, resulting in a lower $\mathrm{CO}$ desorption rate compared with the actual value, which was re-evaluated to be $1.3 \times 10^{-3} \mathrm{~mol} \cdot \mathrm{cm}^{-2} \mathrm{~s}^{-1}$.

Kim et $a l .{ }^{46)}$ studied the carburization of iron with $\mathrm{CO}$ gas by using isotope exchange method and observed the following mechanism.

$$
2 \mathrm{CO}(\mathrm{g}) \rightarrow 2 \mathrm{CO}(\text { ads })
$$




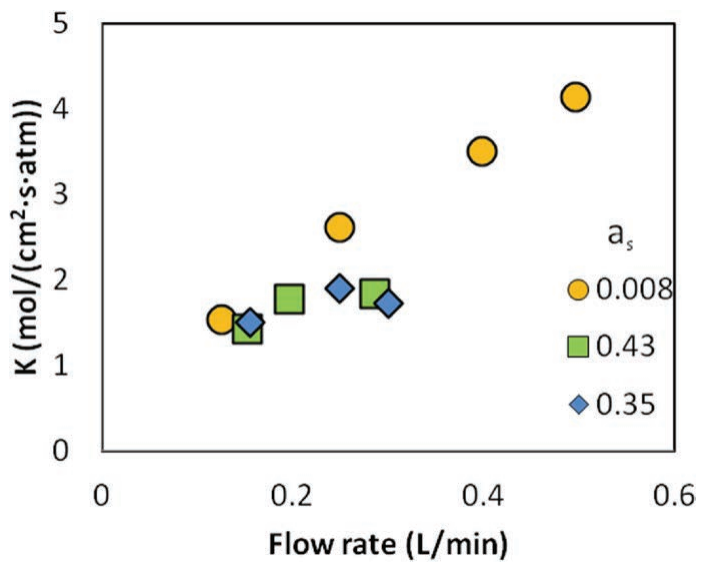

Fig. 7. Rate of the $\mathrm{CO}$ isotope exchange reaction on $\mathrm{Fe}-\mathrm{S}$ alloys at $1600^{\circ} \mathrm{C}^{33)}$ (Online version in color.)

$$
\begin{array}{r}
\mathrm{CO}(\text { ads }) \rightarrow \mathrm{C}(\text { ads })+\mathrm{O}(\text { ads }) \\
\mathrm{CO}(\text { ads })+\mathrm{O}(\text { ads }) \rightarrow \mathrm{CO}_{2} \text { (ads) } \\
\mathrm{CO}_{2} \text { (ads) } \rightarrow \mathrm{CO}_{2} \text { (g) } \ldots . . . . .
\end{array}
$$

For steel with low impurities (oxygen and sulfur activities are less than 0.02), the adsorbed molecules $\mathrm{CO}$ (ads) were found to be easily dissociated into adsorbed atoms, i.e. $\mathrm{C}(\mathrm{ads})$ and $\mathrm{O}$ (ads), as there were sufficient vacant sites around the adsorbed sites by CO (see Fig. 8). The carburization reaction was thus controlled by $\mathrm{CO}$ adsorption. However, for steel containing high impurities (sulfur activity is higher than 0.02 ), the carburization reaction tends to be controlled by the $\mathrm{CO}$ dissociation reaction (i.e. Eq. (10)), as there are fewer available sites to accommodate the dissociated carbon and oxygen atoms. Although the work on the effect of sulfur content on the $\underline{\mathrm{C}}+\underline{\mathrm{O}} \rightleftharpoons \mathrm{CO}_{(\mathrm{g})}$ reaction rate is limited in the literature, a number of studies have been found in decarburization with $\mathrm{CO}_{2}\left(\underline{\mathrm{C}}+\mathrm{CO}_{2(\mathrm{~g})} \rightleftharpoons\right.$ $\left.2 \mathrm{CO}_{(\mathrm{g})}\right)$. It has been observed by many researchers that sulfur can retard the decarburization rate. ${ }^{13,58-64)}$ Hayer et $a l .{ }^{60)}$ studied the decarburization with a $\mathrm{CO}-\mathrm{CO}_{2}(0.1 \mathrm{~atm})$ gas mixture and reported a clear decelerating effect of sulfur on the decarburization rate at a sulfur content between 0 and $0.4 \mathrm{wt} . \%$. As sulfur is a strong surfactant, the melt/gas interface sites are partially occupied by these sulfur atoms in the sulfur-containing melt, leaving less sites available for the gaseous molecules such as $\mathrm{CO}_{2}$ or $\mathrm{O}_{2}$. Thus, the decarburization rate is slowed down. Lee et al. ${ }^{61)}$ investigated the decarburization of an $\mathrm{Fe}-\mathrm{C}$ melt with the levitation technique using a $\mathrm{CO}-\mathrm{CO}_{2}$ gas mixture at $1700^{\circ} \mathrm{C}$. The results clearly indicate that increasing the sulfur content up to 0.05 wt. $\%$ significantly decreases the decarburization rate. At the sulfur content above 0.05 wt. $\%$, the rate of decarburization is approximately $60 \%$ of the value obtained at $0 \mathrm{wt} . \%$ sulfur.

\subsubsection{CO Nucleation}

Rathke and Tarby ${ }^{47}$ ) studied the influence of reduced $\mathrm{CO}$ pressure on the $\underline{\mathrm{C}}-\underline{\mathrm{O}}$ reaction in an $\mathrm{Fe}-0.21 \mathrm{wt} \% \underline{\mathrm{C}}$ melt in a precision casting system (induction melting). As seen in Fig. 9, the efficiency of carbon deoxidation was not significantly increased by vacuum degassing at a chamber pressure below 100 torr $(0.13 \mathrm{~atm})$. The bubble
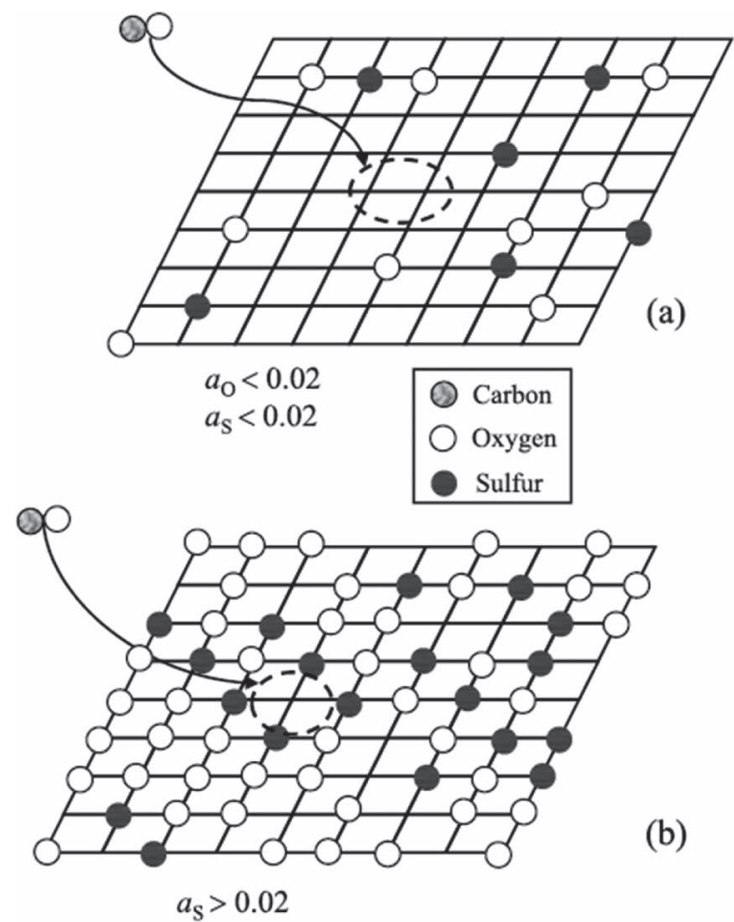

Fig. 8. Change of rate-determining step from (a) $\mathrm{CO}$ adsorption to (b) $\mathrm{CO}$ dissociation with increasing the activities of oxygen and sulfur in the bulk phase at $1550{ }^{\circ} \mathrm{C}$. $^{46}$ )

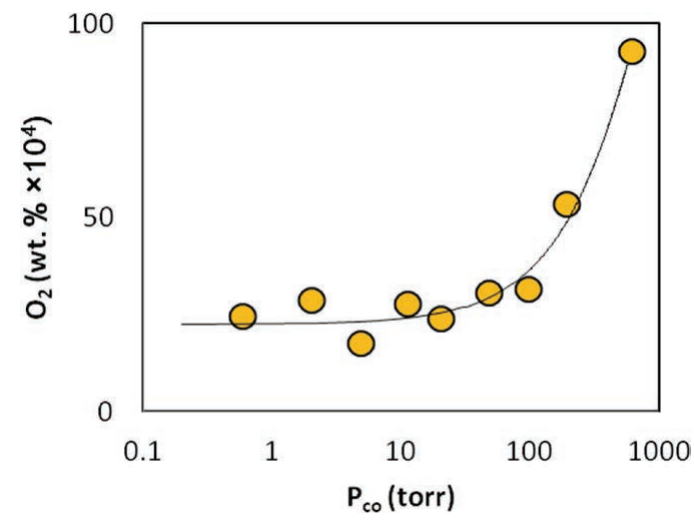

Fig. 9. Average final oxygen content of initially $0.21 \mathrm{wt} \%$ carbon steel melts as a function of the partial pressure of $\mathrm{CO}$ over the bath. ${ }^{47)}$ (Online version in color.)

nucleation mechanism was considered to be the rate-limiting step for vacuum desorption of CO. Similarly, the work of Swisher and Turkdogan, ${ }^{65,66)}$ and the study by Jamieson and Masson ${ }^{67)}$ also confirm that the nucleation phenomenon plays an important role in the decarburization process.

There are a few studies focusing on the melt-slag reaction, involving also $\underline{\mathrm{C}}+\underline{\mathrm{O}} \rightleftharpoons \mathrm{CO}_{(\mathrm{g})}$ reaction. ${ }^{68-72)}$ However, this is beyond the scope of this paper, which focuses on melt-gas interactions.

\section{Summary and Discussion}

The summary of the reviewed papers is listed in Table 1. The kinetics of the $\mathrm{CO}$ absorption and desorption are influenced by various parameters, such as carbon and oxygen content in liquid steel/iron, impurity level (e.g. sulfur content), gas composition ( $\mathrm{CO}$ partial pressure) and flow 
ISIJ International, Vol. 61 (2021), No. 5

Table 1. Summary of the previous investigations.

\begin{tabular}{|c|c|c|c|c|c|c|}
\hline Authors & $\begin{array}{l}\text { Composition of } \\
\text { liquid iron }(\underline{\mathrm{C}}, \underline{\mathrm{O}} \text {, } \\
\underline{\mathrm{S}}, \underline{\mathrm{Al}}) / \mathrm{wt}^{\circ} \%\end{array}$ & Reaction type & $\begin{array}{l}\text { Experimental } \\
\text { technique and } \\
\text { conditions }\end{array}$ & Rate-limiting step & $\begin{array}{l}\text { Important conclusions and } \\
\text { remarks }\end{array}$ & $\begin{array}{c}\text { Year of } \\
\text { published } \\
\text { paper }\end{array}$ \\
\hline Rathke et al. ${ }^{47)}$ & $\underline{\mathrm{C}}: 0.21$ & $\begin{array}{l}\text { CO degassing } \\
\text { under vacuum } \\
(\text { desorption: } \\
\underline{\mathrm{C}}+\underline{\mathrm{O}} \rightarrow \mathrm{CO})\end{array}$ & $\begin{array}{l}\text { Induction } \\
\text { vacuum } \\
\text { melting and } \\
\text { sampling }\end{array}$ & $\begin{array}{l}\text { CO bubble nucleation control in } \\
\text { metal bulk }\end{array}$ & $\begin{array}{l}\underline{\mathrm{C}}-\underline{\mathrm{O}} \text { reaction was not signifi- } \\
\text { cantly increased by vacuum } \\
\text { degassing at chamber pressure } \\
\text { below } 100 \text { torr }(0.13 \mathrm{~atm})\end{array}$ & 1969 \\
\hline Suzuki et $a l .{ }^{34)}$ & $\begin{array}{l}\underline{\mathrm{C}}: 0.01-0.1 \\
\underline{\mathrm{O}}: 0.01-0.09\end{array}$ & $\begin{array}{l}\text { CO desorption } \\
(\underline{\mathrm{C}}+\underline{\mathrm{O}} \rightarrow \mathrm{CO})\end{array}$ & $\begin{array}{l}\text { Induction } \\
\text { melting with } \\
\text { sampling }\end{array}$ & $\begin{array}{l}\underline{\mathrm{O}} \text { mass transfer control for } \underline{\mathrm{C}}>0.03 \\
\mathrm{wt} \%\left(\underline{k}_{\underline{o}}=3.5 \times 10^{-2} \mathrm{~cm} / \mathrm{s}\right) ; \underline{\mathrm{C}} \text { mass } \\
\text { transfer control for } \underline{\mathrm{O}}>0.06 \mathrm{wt} \% \\
\left(k_{c}=5.1 \times 10^{-2} \mathrm{~cm} / \mathrm{s}\right) .\end{array}$ & $\begin{array}{l}\text { The change-over from oxygen } \\
\text { mass transfer control to carbon } \\
\text { mass transfer control occurs at a } \\
\text { ratio of } C_{c} / C_{o}=0.69 \\
\left(C_{c}, C_{o}: \text { concentration of } \underline{\mathrm{C}} \text { and }\right. \\
\left.\underline{\mathrm{O}} \text { in } \mathrm{mol} / \mathrm{cm}^{3}\right)\end{array}$ & 1977 \\
\hline Wang et al. ${ }^{35)}$ & $\begin{array}{l}\text { C: }: 0.257-3.47 \\
\underline{\text { rr: }} 10.3-15.5\end{array}$ & $\begin{array}{l}\text { CO desorption } \\
(\underline{\mathrm{C}}+\underline{\mathrm{O}} \rightarrow \mathrm{CO})\end{array}$ & $\begin{array}{l}\text { Crucible } \\
\text { melting, gas } \\
\text { blowing into } \\
\text { the melt }\end{array}$ & $\begin{array}{l}\text { The decarburization is controlled by } \\
\text { the mass transfer in the liquid iron. }\end{array}$ & $\begin{array}{l}\text { With blowing } \mathrm{CO}_{2} \text {, the utiliza- } \\
\text { tion of the available oxygen for } \\
\text { decarburization was higher as } \\
\text { compared to } \mathrm{O}_{2} \text { injection in the } \\
\text { case of melts containing higher } \\
\text { carbon levels }(>1 \text { wt. } \%) \text {. }\end{array}$ & 2009 \\
\hline Kim et al. ${ }^{73)}$ & & $\begin{array}{l}\mathrm{CO} \text { absorption and } \\
\text { desorption } \\
(\underline{\mathrm{C}}+\underline{\mathrm{O}} \rightleftharpoons \mathrm{CO})\end{array}$ & $\begin{array}{l}\text { Crucible } \\
\text { melting, } \\
\text { based on the } \\
\text { data from } \\
\text { Dancy }{ }^{55)} \text { and } \\
\text { and Lloyd et } \\
\text { al. }^{56)}\end{array}$ & $\begin{array}{l}\text { Forward reaction rate constant, } k= \\
1.33 \times 10^{8} \exp (-250000 / \mathrm{RT}), \mathrm{mol} / \\
\left(\mathrm{m}^{2} \mathrm{~s}\right) \\
\text { backward reaction rate constant, } \mathrm{k}= \\
2.40 \times 10^{11} \exp (-277000 / \mathrm{RT}), \mathrm{mol} / \\
\left(\mathrm{m}^{2} \mathrm{~s}\right)\end{array}$ & & 2010 \\
\hline Parlee et al. ${ }^{36)}$ & C: $0.15-4.4$ & $\begin{array}{l}\mathrm{CO} \text { absorption and } \\
\text { desorption } \\
(\underline{\mathrm{C}}+\underline{\mathrm{O}} \rightleftharpoons \mathrm{CO})\end{array}$ & $\begin{array}{l}\text { Sieverts type } \\
\text { (at constant } \\
\text { pressure), } \\
\text { inductively } \\
\text { stirred melts }\end{array}$ & $\begin{array}{l}\underline{\mathrm{O}} \text { mass transfer control in metal, } \\
k_{o}=2 \sim 3 \times 10^{-3} \mathrm{~cm} / \mathrm{s} \text { (for } \mathrm{C}=0.15- \\
0.95 \mathrm{wt} \% \text { ) } k_{o}=1 \sim 2 \times 10^{-2} \mathrm{~cm} / \mathrm{s} \text { for } \\
\mathrm{C}<0.1 \mathrm{wt} \%\end{array}$ & $\begin{array}{l}\text { a) For high } \underline{\mathrm{C}} \text { content, crucible } \\
\text { reaction occurs; b) the direction } \\
\text { of the reaction (i.e. absorption or } \\
\text { desorption) did not influence the } \\
\text { kinetics of the process }\end{array}$ & 1958 \\
\hline King et al. ${ }^{37)}$ & $\underline{\mathrm{C}}: \sim 4.5$ & $\begin{array}{l}\mathrm{CO} \text { absorption and } \\
\text { desorption } \\
(\underline{\mathrm{C}}+\underline{\mathrm{O}} \rightleftharpoons \mathrm{CO})\end{array}$ & $\begin{array}{l}\text { Sieverts type, } \\
\text { naturally- } \\
\text { convecting } \\
\text { melts }\end{array}$ & $\begin{array}{l}\underline{\mathrm{O}} \text { mass transfer control for absorp- } \\
\text { tion in all } \underline{\mathrm{C}} \text { content and desorption } \\
\text { in } \underline{\mathrm{C}}>0.2 \mathrm{wt} \%\end{array}$ & $\begin{array}{l}\text { For low } \underline{\mathrm{C}} \text { steel }(\sim 0.05 \text { wt } \% \underline{\mathrm{C}}) \\
\text { desorption rate was anomalously } \\
\text { slow due to sites limited in avail- } \\
\text { ability by strong adsorption of } \\
\text { oxygen }\end{array}$ & 1970 \\
\hline Solar et al. ${ }^{29)}$ & $\begin{array}{l}\underline{\mathrm{C}}: \sim 0.008 \\
\underline{\mathrm{O}}:\end{array}$ & $\begin{array}{l}\mathrm{CO} \text { absorption } \\
(\mathrm{CO} \rightarrow \underline{\mathrm{C}}+\underline{\mathrm{O}})\end{array}$ & $\begin{array}{l}\text { Sieverts type } \\
\text { (at constant } \\
\text { volume), } \\
\text { stagnant iron }\end{array}$ & $\begin{array}{l}\text { Simultaneous mass transfer control } \\
\text { of } \underline{\mathrm{C}} \text { and } \underline{\mathrm{O}} ; \\
D_{c o}=9.8 \times 10^{-5} \mathrm{~cm}^{2} / \mathrm{s} \text { ('apparent } \\
\text { diffusion coefficient' of } \mathrm{CO} \text { ) }\end{array}$ & $\begin{array}{l}\text { The 'apparent diffusion coeffi- } \\
\text { cient' of CO, Dco, essentially } \\
\text { took into account both carbon } \\
\text { and oxygen diffusivity. }\end{array}$ & 1972 \\
\hline Schenck et al. ${ }^{28)}$ & & $\begin{array}{l}\text { CO desorption } \\
(\underline{\mathrm{C}}+\underline{\mathrm{O}} \rightarrow \mathrm{CO})\end{array}$ & $\begin{array}{l}\text { Sieverts type } \\
\text { (at constant } \\
\text { pressure) }\end{array}$ & $\begin{array}{l}\text { Mass transfer control in liquid phase } \\
(\underline{\mathrm{C}} \text { and } \underline{\mathrm{O}}) ; \\
D_{o}=22 \times 10^{-5} \mathrm{~cm}^{2} \mathrm{~s}^{-1}\left(1600^{\circ} \mathrm{C}\right)\end{array}$ & $\begin{array}{l}\text { In low } \underline{\mathrm{C}}, \text { desorption rate } \\
\text { increase with } \underline{\mathrm{C}} \text {, in high } \underline{\mathrm{C}} \text {, how- } \\
\text { ever, with the reciprocal value of } \\
\underline{\mathrm{C}} \text { content. }\end{array}$ & $\begin{array}{l}1971 \\
1973\end{array}$ \\
\hline Baker et al. ${ }^{39)}$ & $\underline{\mathrm{C}}: 0-5.5$ & $\begin{array}{l}\text { Decarburization } \\
\text { by blowing gas } \\
\text { mixture contain- } \\
\text { ing } \mathrm{O}_{2} \\
\left(\underline{\mathrm{C}}+\mathrm{O}_{2} \rightarrow \mathrm{CO}\right)\end{array}$ & $\begin{array}{l}\text { Levitated } \\
\text { droplet } \\
\text { experiments }\end{array}$ & $\begin{array}{l}\mathrm{O}_{2} \text { mass transfer control in gas phase } \\
\text { for high } \underline{\mathrm{C}} \text { steel; } \underline{\mathrm{C}} \text { mass transfer con- } \\
\text { trol for low } \underline{\mathrm{C}} \text { steel }\end{array}$ & $\begin{array}{l}\text { An equation was derived to pre- } \\
\text { dict the rate of oxygen diffusion } \\
\text { to the droplet through the gas } \\
\text { boundary layer }\end{array}$ & 1967 \\
\hline Distin et al. ${ }^{30)}$ & $\underline{\mathrm{C}}: \sim 4.0$ & $\begin{array}{l}\text { Decarburization } \\
\text { by blowing } \mathrm{O}_{2} \\
\mathrm{CO}_{2}, \mathrm{O}_{2}+\mathrm{H}_{2} \mathrm{O} \\
\text { and } \mathrm{O}_{2}+\mathrm{Ar} \\
\left(\underline{\mathrm{C}}+\mathrm{O}_{2} \rightarrow \mathrm{CO}\right)\end{array}$ & $\begin{array}{l}\text { Levitated } \\
\text { droplet } \\
\text { experiments }\end{array}$ & $\begin{array}{l}\mathrm{O}_{2} \text { mass transfer control in gas phase; } \\
k_{o}=2 \sim 3 \times 10^{-3} \mathrm{~cm} / \mathrm{s} \\
k_{c}=3.2 \times 10^{-2} \mathrm{~cm} / \mathrm{s}\end{array}$ & $\begin{array}{l}\text { Oxygen absorption to the liquid } \\
\text { droplet during the tests is very } \\
\text { slow. }\end{array}$ & 1968 \\
\hline Ito et al..$^{31,40,41)}$ & $\begin{array}{l}\text { C: } 0.028-0.095 \\
\underline{\mathrm{O}}: 0.03-0.09\end{array}$ & $\begin{array}{l}\text { CO desorption } \\
(\underline{\mathrm{C}}+\underline{\mathrm{O}} \rightarrow \mathrm{CO})\end{array}$ & $\begin{array}{l}\text { Both levita- } \\
\text { tion and } \\
\text { crucible } \\
\text { melting }\end{array}$ & $\begin{array}{l}\text { Desorption controlled jointly by mass } \\
\text { transfer of } \underline{\mathrm{C}} \text { or } \underline{\mathrm{O}} \text { in metal and that of } \\
\mathrm{CO} \text { in gas phase } \\
k_{o}=4.1 \sim 5.0 \times 10^{-2} \mathrm{~cm} / \mathrm{s} \\
k_{c}=4.5 \sim 5.6 \times 10^{-2} \mathrm{~cm} / \mathrm{s}\end{array}$ & $\begin{array}{l}\text { a. For levitation melting the } \mathrm{CO} \\
\text { desorption proceeds stoichio- } \\
\text { metrically obeying to } \underline{\mathrm{C}}+\underline{\mathrm{O}}= \\
\mathrm{CO} \text { until carbon or oxygen is } \\
\text { depleted; b. Crucible corrosion } \\
\text { leads to an increase in } \underline{\mathrm{O}} \text { in the } \\
\text { liquid iron. }\end{array}$ & $\begin{array}{l}1975 \\
1977 \\
1984\end{array}$ \\
\hline Brabie $^{51)}$ & $\begin{array}{l}\text { C: } 0.004 \\
\underline{\text { Al }}: 0.02-0.4\end{array}$ & $\begin{array}{l}\mathrm{CO} \text { absorption by } \\
\text { Al-killed steel } \\
(2 \underline{\mathrm{Al}}+3 \mathrm{CO} \rightarrow \\
\left.\mathrm{Al}_{2} \mathrm{O}_{3}+\underline{\mathrm{C}}\right)\end{array}$ & $\begin{array}{l}\text { Levitation } \\
\text { droplet } \\
\text { method }\end{array}$ & N.A. & $\begin{array}{l}\text { CO absorption by Al-killed } \\
\text { steel occurs in two stages: a } \\
\text { first stage of rapid absorption, } \\
\text { and the second stage of slow } \\
\text { absorption in the presence of an } \\
\text { alumina film covering the drop- } \\
\text { let. }\end{array}$ & 1998 \\
\hline
\end{tabular}




\begin{tabular}{|c|c|c|c|c|c|c|}
\hline $\begin{array}{l}\text { Simento } \\
\text { et al. }^{42-44)}\end{array}$ & $\begin{array}{l}\underline{\mathrm{C}}: 3-4 \\
\underline{\mathrm{S}}:<0.27\end{array}$ & $\begin{array}{l}\text { CO desorption } \\
(\underline{\mathrm{C}}+\underline{\mathrm{O}} \rightarrow \mathrm{CO})\end{array}$ & $\begin{array}{l}\text { Levitation } \\
\text { droplet } \\
\text { method }\end{array}$ & $\begin{array}{l}\text { The decarburization rate with }(1) \mathrm{O}_{2} \text { : } \\
\text { limited by the transport of oxygen in } \\
\text { the bulk gas, (2) } \mathrm{CO}_{2} \text { : jointly con- } \\
\text { trolled by gas phase mass transport } \\
\text { and dissociative chemisorption of car- } \\
\text { bon dioxide, (3) } \mathrm{O}_{2}+\mathrm{CO}_{2} \text { : limited by } \\
\mathrm{O}_{2} \text { and } \mathrm{CO}_{2} \text { transport in the gas phase } \\
\text { and the interfacial reaction kinetics of } \\
\mathrm{CO}_{2},(4) \mathrm{O}_{2}+\mathrm{H}_{2} \mathrm{O} \text { : similar to that of } \\
\mathrm{O}_{2}+\mathrm{CO}_{2} \text {, but the reaction between } \mathrm{O}_{2} \\
\text { and } \mathrm{CO} \text { to produce } \mathrm{CO}_{2} \text { occurs in the } \\
\text { vicinity of the interface, lowering the } \\
\text { decarburization rate. }\end{array}$ & & $\begin{array}{l}1998, \\
1999\end{array}$ \\
\hline Widlund et $a l^{45)}$ & $\begin{array}{l}\underline{\mathrm{C}}: 4.0 \\
\underline{\mathrm{Si}}: 0.37-0.71\end{array}$ & $\begin{array}{l}\text { CO desorption } \\
(\underline{\mathrm{C}}+\underline{\mathrm{O}} \rightarrow \mathrm{CO})\end{array}$ & $\begin{array}{l}\text { Levitation } \\
\text { droplet } \\
\text { method }\end{array}$ & Mass transfer in gas phase & $\begin{array}{l}\text { The decarburization rate } \\
\text { increases from } 0.11 \text { to } 0.17 \% \\
\text { when the oxygen partial pressure } \\
\text { increases from } 10 \text { to } 20 \% \text { in the } \\
\mathrm{He}-\mathrm{O}_{2} \text { mixture, indicating a gas } \\
\text { mass transfer-controlled mecha- } \\
\text { nism }\end{array}$ & 2006 \\
\hline Fruehan et al. ${ }^{33)}$ & $\begin{array}{l}\underline{\mathrm{C}}: 0.01-4.5 \\
\underline{\mathrm{S}}: 0.008-0.43\end{array}$ & $\begin{array}{l}\mathrm{C}^{13} \mathrm{O}^{18} \text { dissociation } \\
\left(\mathrm{C}^{13} \mathrm{O}^{18} \rightarrow \mathrm{C}^{13}+\right. \\
\left.\mathrm{C}^{18}\right)\end{array}$ & $\begin{array}{l}\text { Isotope } \\
\text { exchange } \\
\text { technique }\end{array}$ & $\begin{array}{l}\text { Mixed control by chemical reaction } \\
\text { and gas phase mass transfer for low } \\
\text { temperature and } \underline{\mathrm{S}}>0.15 \% \mathrm{wt} \text {; rate } \\
\text { constant } k=1.5 \times 10^{-5} \mathrm{~mol} \cdot \mathrm{cm}^{-2} \mathrm{~s}^{-1} \text {. }\end{array}$ & $\begin{array}{l}\text { Chemical rate is one order of } \\
\text { magnitude larger than previ- } \\
\text { ously measured when the rate } \\
\text { was controlled by liquid phase } \\
\text { mass transfer. }\end{array}$ & 1987 \\
\hline Sasaki et al. ${ }^{52)}$ & $\begin{array}{l}\underline{\mathrm{O}}: 0.04 \\
\underline{\mathrm{C}}: 0.02 \\
\underline{\mathrm{Al}}: 0.007 \\
\underline{\mathrm{S}}: 0.005\end{array}$ & $\begin{array}{l}\mathrm{CO}(\text { ads }) \rightarrow \mathrm{C}(\mathrm{ads}) \\
+\mathrm{O}(\mathrm{ads})\end{array}$ & $\begin{array}{l}\text { Isotope } \\
\text { exchange } \\
\text { technique }\end{array}$ & $\begin{array}{l}\text { Re-evaluated reaction rate constant } \\
\text { as } 1.3 \times 10^{-3} \mathrm{~mol} \cdot \mathrm{cm}^{-2} \mathrm{~s}^{-1}\end{array}$ & $\begin{array}{l}\text { Re-examined the reaction con- } \\
\text { stant measured by Fruehan et al. }\end{array}$ & 2004 \\
\hline Kim et al. ${ }^{46)}$ & $\begin{array}{l}\text { C: } 0.0019-3.3100 \\
\underline{\mathrm{O}}: 0.0020-0.6170 \\
\underline{\mathrm{S}}: 0.0026-0.018 \\
\underline{\mathrm{N}}: 0.003-0.0821\end{array}$ & $\begin{array}{l}2 \mathrm{CO}(\mathrm{g})+\mathrm{Fe}(\mathrm{l}) \rightarrow \\
\mathrm{C} \text { in } \mathrm{Fe}+\mathrm{CO}_{2}\end{array}$ & $\begin{array}{l}\text { Isotope } \\
\text { exchange } \\
\text { technique }\end{array}$ & $\begin{array}{l}\text { Interfacial reaction at gas-metal sur- } \\
\text { face can be converted from adsorp- } \\
\text { tion limited control to dissociation } \\
\text { limited reaction, as the impurity } \\
\text { concentrations of oxygen and sulfur } \\
\text { increase. }\end{array}$ & $\begin{array}{l}\text { In particular, it was found that } \\
\text { sulfur has a greater influence } \\
\text { on the conversion of the } \\
\text { rate-limiting step of the carbu- } \\
\text { rization reaction of molten iron }\end{array}$ & 2013 \\
\hline $\operatorname{Fan}^{53)}$ & C: $: 1-4$ & $\begin{array}{l}\text { CO desorption } \\
(\underline{\mathrm{C}}+\underline{\mathrm{O}} \rightarrow \mathrm{CO})\end{array}$ & $\begin{array}{l}\text { Isotope } \\
\text { tracing } \\
\text { technique }\end{array}$ & N.A. & $\begin{array}{l}\text { Their results indicate that the } \\
\text { utilization rate of } \mathrm{CO}_{2} \text { exceeds } \\
97 \% \text {, whereas approximately } \\
52 \% \text { of oxygen reacted with } \mathrm{C} \text { in } \\
\text { the melt and form } \mathrm{CO} \text { and } 17 \% \\
\text { form } \mathrm{CO}_{2} \text {. The rest of oxygen } \\
\text { was reacted during post combus- } \\
\text { tion. }\end{array}$ & 2019 \\
\hline
\end{tabular}

$D_{O}, D_{C}$ : diffusion coefficient of oxygen and carbon respectively.

$k_{O}, k_{C}$ : mass transfer coefficient of oxygen and carbon respectively.

rate, temperature, and even refractory materials $\left(\mathrm{Al}_{2} \mathrm{O}_{3}\right.$ and $\mathrm{MgO}$ ). However, as seen from Table 1, particularly in the work of Suzuki et al. ${ }^{34)}$ Parlee et al., ${ }^{36)}$ Distin et al., ${ }^{30)}$ and Ito et al., ${ }^{31,40,41)}$ although the experimental conditions (temperature, steel/iron composition, etc.) were different, the measured mass transfer coefficient of oxygen is always smaller than that of carbon in liquid iron/steel. This indicates that at the same concentration gradient (from liquid bulk to gas-liquid interface), oxygen transfer in the liquid phase is more likely to be the rate-controlling step compared with carbon. However, at either low carbon concentration or high oxygen content, the $\underline{\mathrm{C}}+\underline{\mathrm{O}} \rightarrow \mathrm{CO}$ reaction rate is controlled by the mass transfer of carbon in liquid steel, as confirmed by Baker $(\underline{\mathrm{C}}<1$ wt.\%) and Suzuki $(\underline{\mathrm{O}}>0.06$ wt.\%). The gas phase diffusion was omitted in the discussion of $\mathrm{CO}$ desorption/absorption by many researchers, such as Rathke et al., ${ }^{47)}$ Suzuki et al. ${ }^{34)}$ Parlee et al. ${ }^{36)} \mathrm{King}$ et $a l .{ }^{37)}$ Solar et al. ${ }^{29)}$ and Schenck et al. ${ }^{28)}$ Nevertheless, it was found to be the rate-limiting step for the $\mathrm{CO}$ absorption or desorption in the work of Baker et al. ${ }^{39)}$ Distin et al. ${ }^{30)}$ and Ito et al. ${ }^{31,40,41)}$ This contradiction is mainly attributed to the characteristics of the distinct experimental set-ups. In the experiment with furnace melting, the gas flow rate was optimized until the reaction rate was independent of the flow rate (e.g. $1500 \mathrm{~mL} / \mathrm{min}$ in Suzuki et al.'s work ${ }^{34)}$ and 2000 $\mathrm{mL} / \mathrm{min}$ in Ito et al.'s study ${ }^{31)}$ ). Hence, the gas phase mass transfer was eliminated in the rate-liming step discussion, with the research mainly focusing on the liquid phase diffusion. On the contrary, in the levitated droplet experiment, one of the important purposes is to study the effect of gas flow rate (varying in a wide range such as $270-3000 \mathrm{~mL} /$ min in Ito et al.'s study ${ }^{31,40}$ ) on the reaction rate. The gas flow rate was controlled to be in a wide range, so that gas phase mass transfer could become the rate-limiting step for the reaction in the lower gas flow rate conditions/regions. To provide a comprehensive picture of the $\mathrm{CO}$ - liquid iron/ steel reaction under a wider range of experimental conditions (temperature, gas/melt composition, gas flow rate, etc.), it is of paramount importance to examine the experimental result by taking the corresponding technique into consideration. Alternatively, a novel experimental set-up is requested, which enables the investigation of mass transfer 
in both the gas and the liquid phase, while also allowing the measurement of the interfacial reaction rate.

Moreover, it is noticed that the gas-liquid interfacial reaction (for $\mathrm{CO}$ absorption and desorption) is measured to be much faster than the mass transfer in the liquid or gas phase. The reaction rate constant measured by Fruehan et al. ${ }^{33)}$ is $5.4 \times 10^{-5} \mathrm{~mol} \cdot \mathrm{cm}^{-2} \mathrm{~s}^{-1}$ at $1250^{\circ} \mathrm{C}$ for steel containing 0.1 wt. $\% \underline{\mathrm{S}}$. This is an order of magnitude larger than the previously measured reaction rate constant of the $\mathrm{CO}$-liquid steel reaction when the process was controlled by liquid phase mass transfer. Therefore, the measured reaction rate in Fruehan et al.'s experiment, ${ }^{33)}$ in which there is no liquid phase mass transfer limitation, is considerably more rapid than the situation where the mass transfer limitation is taken into account. Sasaki et al. ${ }^{52)}$ re-measured the chemical rate constant; they obtained a value of $1.3 \times 10^{-3} \mathrm{~mol} \cdot \mathrm{cm}^{-2} \mathrm{~s}^{-1}$, which was even two orders of magnitude higher than the value estimated by Fruehan et al. $\left.{ }^{33}\right)$ However, in King et al.'s work ${ }^{37)}$ for low $\underline{\mathrm{C}}$ steel $(\sim 0.05 \mathrm{wt} \% \mathrm{C})$, the $\mathrm{CO}$ desorption rate was anomalously slower than the $\mathrm{CO}$ absorption rate. This was considered to be caused by the slow interfacial reaction, as there are limited available sites at the gas-melt interface due to the strong adsorption of oxygen. Kim et $a l .{ }^{46)}$ investigated the kinetics of $\mathrm{CO}$ absorption into molten iron and found that sulfur has a larger impact on the interfacial chemical reaction with respect to oxygen. In liquid iron containing high impurities ( $\mathrm{S}$ activity $>0.02$ wt $\%$ ), it is observed that the absorbed CO molecules at the gas/liquid interface are difficult to dissociate into atoms due to fewer vacant sites around them (the sites are occupied by sulfur atoms). Hence, the impurity level can significantly reduce the reaction rate during $\mathrm{CO}$ absorption. However, in the $\mathrm{CO}$ desorption, in addition to the quantity of available sites at the gas-melt interface (determined by sulfur and oxygen content), the CO nucleation, as observed by many researchers ${ }^{65,66)}$ may also play a critical role in determining the overall gas-melt reaction rate. For this reason, the $\mathrm{CO}$ absorption and desorption rate in molten iron/steel may significantly vary. Further experimental work on the kinetics of CO absorption and desorption with thoroughly controlled parameters, such as steel composition and interface area, are suggested. Moreover, an in-depth study on the interfacial reaction is required.

\section{Conclusions}

In the present work, the previous research on the $\mathrm{CO}$ absorption and desorption was reviewed. The experimental techniques were summarized and compared with each other. The $\mathrm{C}-\mathrm{O}$ reaction mechanism was analyzed and discussed. Future work is suggested in order to clarify the $\mathrm{CO}$ absorption and desorption mechanism in liquid steel/iron. The conclusions are drawn as follows:

(1) A number of factors affect the kinetics of $\mathrm{CO}$ absorption and/or desorption by liquid steel/iron. These factors include temperature, steel composition ( $\underline{\mathrm{O}}, \underline{\mathrm{C}}, \underline{\mathrm{S}}$, $\underline{\mathrm{Al}}), \mathrm{CO}$ partial pressure in the gas phase, stirring condition of the liquid phase, gas flow rate, and even the employed crucible materials.

(2) The overall reaction of $\mathrm{CO}$ absorption (and/or desorption) by liquid $\mathrm{Fe}-\underline{\mathrm{C}}-\underline{\mathrm{O}}$ alloys can be broken down into several steps, i.e. 1) transport of the dissolved carbon and oxygen in the metal phase, 2) chemical reaction at the gas/metal interface $(\underline{\mathrm{C}}+\underline{\mathrm{O}} \rightleftharpoons \mathrm{CO})$ and 3$)$ transport of $\mathrm{CO}$ in a boundary layer of gas phase. In most studies, the ratelimiting step was determined to be 1) the mass transfer of $\underline{\mathrm{C}}$ and $\underline{\mathrm{O}}$ in the metal phase or 3 ) the transport of $\mathrm{CO}$ in gas phase, while 2) the chemical reaction rate at the interface was measured to be at least one order of magnitude larger than the mass transfer rate in the melt phase.

(3) When gas phase mass transfer is eliminated in the experiment, it can be generally concluded that the overall reaction is controlled by $\underline{\mathrm{O}}$ mass transfer for high $\underline{\mathrm{C}}$ steel $(\underline{\mathrm{C}}>0.2 \mathrm{wt} \%)$ and jointly by mass transfer of $\underline{\mathrm{C}}$ and $\underline{\mathrm{O}}$ for low $\underline{\mathrm{C}}$ steel $(\underline{\mathrm{C}}<0.03 \mathrm{wt} \%)$. The mass transfer coefficients of oxygen and carbon were estimated to be, respectively, $k_{o} \approx 0.2 \times 10^{-2}-5.0 \times 10^{-2} \mathrm{~cm} / \mathrm{s}$ and $k_{c} \approx 3.2 \times 10^{-2}-5.6 \times$ $10^{-2} \mathrm{~cm} / \mathrm{s}$, i.e. varying with carbon and oxygen content.

(4) For the decarburization reaction of steel by blowing a gas mixture containing $\mathrm{O}_{2}\left(\underline{\mathrm{C}}+\mathrm{O}_{2} \rightarrow \mathrm{CO}\right)$, the rate-limiting step was found to be, respectively, $\mathrm{O}_{2}$ mass transfer in gas phase for high $\underline{\mathrm{C}}$ steel $(\underline{\mathrm{C}}>0.2 \mathrm{wt} \%)$ and $\underline{\mathrm{C}}$ mass transfer in the metal phase for low $\underline{\mathrm{C}}$ steel $(\underline{\mathrm{C}}<$ $0.1 \mathrm{wt} \%)$.

(5) The interfacial reaction at the CO-liquid steel surface can be converted from $\mathrm{CO}$ adsorption-limited control to dissociation-limited reaction as the impurity concentrations of oxygen and sulfur increase (e.g. sulfur activity > 0.02). Further studies with special attention to the interfacial reaction are suggested.

\section{REFERENCES}

1) R. Fruehan, D. Goldstein, B. Sarma, S. Story, P. Glaws and H. Pasewicz: Metall. Mater. Trans. B, 31 (2000), 891.

2) E. T. Turkdogan: Fundamentals of Steelmaking, The Institute of Materials, London, (1996), 51.

3) J. F. Elliott and M. Gleiser: Thermochemistry for Steelmaking, Addison-Wesley Pub. Co., Reading, (1963), 10.

4) H. Meyer, W. Porter, G. Smith and J. Szekely: JOM, 20 (1968), 35.

5) N. Themelis and P. Goyal: Can. Metall. Q., 22 (1983), 313.

6) K. Dong and X. Wang: Metals, 9 (2019), 273.

7) E. T. Turkdogan: Physical Chemistry of High Temperature Technology, Academic Press, London, (1980), 9.

8) S. Kitamura, H. Aoki, K. Miyamoto, H. Furuta, K. Yamashita and K. Yonezawa: ISIJ Int., 40 (2000), 455.

9) D. Guo and G. Irons: Metall. Mater. Trans. B, 31 (2000), 1447.

10) H. Dharwadkar and A. Ghosh: Metall. Trans. B, 17 (1986), 553

11) K. McCutcheon and J. Chipman: Trans. AIME, 131 (1938), 206.

12) J. Feinman and D. R. Mac Rae: Direct Reduced Iron: Technology and Economics of Production and Use, Iron \& Steel Society, Warrendale, PA, (1999), 53.

13) H. D. Zughbi: Scand. J. Metall., 33 (2004), 242.

14) Y. Kishimoto, K. Taoka and S. Takeuchi: Kawasaki Steel Tech. Rep., (1997), No. 37, 51

15) D. Mombelli, C. Mapelli, S. Barella, A. Gruttadauria, R. Sosio, G. Valentino and V. Ancona: Steel. Res. Int., 89 (2018), 1700467.

16) L. De Vos, I. Bellemans, C. Vercruyssen and K. Verbeken: Metall. Mater. Trans. B, 50 (2019), 2647.

17) C. Liu, P. L. L. Gonzalez, S. Huang, Y. Pontikes, B. Blanpain and M. Guo: Metall. Mater. Trans. B, 50 (2019), 1260.

18) A. Quiyoom, S. Ajmani and V. V. Buwa: Chem. Eng. J., 346 (2018), 127.

19) S. Neumann, A. Asad, T. Kasper and R. Schwarze: Metall. Mater. Trans. B, 50 (2019), 2334.

20) M.-A. Van Ende, Y.-M. Kim, M.-K. Cho, J. Choi and I.-H. Jung: Metall. Mater. Trans. B, 42 (2011), 477.

21) M.-A. Van Ende and I.-H. Jung: Computational Materials System Design, Springer, Cham, (2018), 47.

22) N. Dogan, G. A. Brooks and M. A. Rhamdhani: ISIJ Int., 51 (2011), 1102 .

23) M. A. Barron, D. Y. Medina and I. Hilerio: Model. Numer. Simul. Mater. Sci., 4 (2014), 94.

24) N. Dogan, G. A. Brooks and M. A. Rhamdhani: ISIJ Int., 51 (2011), 1086. 
25) N. Dogan, G. A. Brooks and M. A. Rhamdhani: ISIJ Int., 51 (2011), 1093.

26) S. Barella, C. Mapelli, D. Mombelli, A. Gruttadauria, E. Laghi, V. Ancona and G. Valentino: Ironmaking Steelmaking, 46 (2019), 721.

27) A. Asad, M. Haustein, K. Chattopadhyay, C. G. Aneziris and R. Schwarze: JOM, 70 (2018), 2927.

28) H. Schenck, E. Steinmetz and R. Thielmann: Arch. Eisenhuttenwes., 42 (1971), 79.

29) M. Solar and R. Guthrie: Metall. Mater. Trans. B, 3 (1972), 713.

30) P. Distin, G. Hallett and F. Richardson: J. Iron Steel Inst., 206 (1968), 821.

31) K. Ito, K. Amano and H. Sakao: Trans. Iron Steel Inst. Jpn., 17 (1977), 685.

32) V. Brabie: Scand. J. Metall., 25 (1996), 148.

33) R. Fruehan and S. Antolin: Metall. Trans. B, 18 (1987), 415.

34) K. Suzuki and K. Mori: Trans. Iron Steel Inst. Jpn., 17 (1977), 136.

35) H. Wang, N. N. Viswanathan, N. B. Ballal and S. Seetharaman: High Temp. Mater. Process., 28 (2009), 407.

36) N. Parlee, S. Seagle and R. Schuhmann: Trans. Am. Inst. Min. Metall. Eng., 212 (1958), 132.

37) T. King, R. Karasev and P. Dastur: Heterogeneous Kinetics at Elevated Temperatures, Plenum Press, New York, (1970), 409.

38) H. Schenck, E. Steinmetz and R. Thielmann: Arch. Eisenhuttenwes., 44 (1973), 27.

39) L. Baker, N. Warner and A. Jenkins: Trans. Metall. Soc. AIME, 239 (1967), 857.

40) K. Ito, K. Amano and H. Sakao: Tetsu-to-Hagané, 61 (1975), 312 (in Japanese).

41) K. Ito, K. Amano and H. Sakao: Trans. Iron Steel Inst. Jpn., 24 (1984), 515.

$42) \quad$ N. Simento, H. G. Lee and P. Hayes: Steel. Res., 69 (1998), 318.

$43)$ N. Simento, H. G. Lee and P. C. Hayes: Steel. Res., 69 (1998), 349.

$44)$ N. J. Simento, H.-G. Lee and P. C. Hayes: ISIJ Int., 39 (1999), 1217.

45) D. Widlund, D. S. Sarma and P. G. Jonsson: ISIJ Int., 46 (2006), 1149 .

46) H. Kim, D.-J. Min and S.-M. Jung: ISIJ Int., 53 (2013), 199.
47) A. Rathke and S. Tarby: Trans. Metall. Soc. AIME, 245 (1969), 119.

48) A.-H. Bui, T.-H. Le and B.-T. Nguyen: ASEAN Eng. J. Part B, 3 (2014), 55.

49) A. J. Lachawiec, Jr., T. R. DiRaimondo and R. T. Yang: Rev. Sci. Instrum., 79 (2008), 063906.

50) M. Solar and R. Guthrie: Metall. Trans., 2 (1971), 457.

51) V. Brabie: Scaninject VII, Part I, Lulea, Sweden, (1995), 165.

52) Y. Sasaki and K. Ishii: ISIJ Int., 44 (2004), 439.

53) Y. Fan, X. Hu, R. Zhu and K. Chou: ISIJ Int., 60 (2020), 848

54) H. Knüppel and F. Oeters: Arch. Eisenhuttenwes., 33 (1962), 729.

55) T. Dancy: J. Iron Steel Inst., 169 (1951), 17.

56) G. W. Lloyd, D. R. Young and L. A. Baker: Ironmaking Steelmaking, 2 (1975), 49

57) S. Whiteway, R. Peters, W. Jamieson and C. Masson: Can. Metall. Q., 7 (1968), 211.

58) D. Sain and G. Belton: Metall. Trans. B, 7 (1976), 235.

59) D. Sain and G. Belton: Metall. Trans. B, 9 (1978), 403.

60) M. Hayer and S. Whiteway: Can. Metall. Q., 12 (1973), 23.

61) H. Lee and Y. Rao: Metall. Trans. B, 13 (1982), 403.

62) D. Ghosh: Ironmaking Steelmaking, 2 (1975), 45.

$63)$ R. Fruehan and L. Martonik: Metall. Trans., 5 (1974), 1027.

64) H. Nomura and K. Mori: Trans. Iron Steel Inst. Jpn., 13 (1973), 325.

65) J. Swisher and E. Turkdogan: Trans. Metall. Soc. AIME, 239 (1967), 602.

66) J. Swisher and E. Turkdogan: Trans. Metall. Soc. AIME, 239 (1967), 426.

67) W. Jamieson and C. Masson: J. Am. Chem. Soc., 84 (1962), 4084

68) A. Kadrolkar and N. Dogan: Metall. Mater. Trans. B, 50 (2019), 2912.

69) K. Gu, N. Dogan and K. S. Coley: Metall. Mater. Trans. B, 48 (2017), 2343.

70) K. Gu, N. Dogan and K. S. Coley: Metall. Mater. Trans. B, 48 (2017), 2984.

71) D.-J. Min and R. Fruehan: Metall. Trans. B, 23 (1992), 29

72) E. Chen and K. S. Coley: Ironmaking Steelmaking, 37 (2010), 541

73) H.-S. Kim, J. G. Kim and Y. Sasaki: ISIJ Int., 50 (2010), 678. 